\title{
The Nigeria Criminal Justice System And Its Effectiveness In Criminal Behaviour Control: A Social-Psychological Analysis
}

\author{
Tosin T. Olonisakin, Adedeji J. Ogunleye, and, Sulaiman O. Adebayo \\ Department of Psychology and Behavioral Sciences \\ Faculty of the Social Sciences \\ Ekiti State University, Ado Ekiti; Nigeria. \\ Corresponding authors email: dr.ajogunleye@gmail.com
}

\begin{abstract}
In the wake of seemingly normalized criminality and its unabated wave in Nigeria and the need for concerted efforts to understand its pervasiveness, this paper examines the role of the Nigeria criminal justice system (CJS) in criminal behavior control. The effectiveness of the CJS was analyzed as an instrument of socialjustice and criminal behavior control. From the point of view of some social-psychological theories and concepts, the paper submitted that the lack of credibility on the part of the communicators,the Nigeria CJS (i. e. the police, lawyers, judges, and the prisons), in their administration of justice and the laws has been responsible for an avalanche of socialinjustice, lack of discipline and lawlessness in Nigeria and Nigerians. The Nigeria CJS, who constitutes the supposed custodians of the laws, is largely indicted, therefore as responsible for the ineffectiveness of the system in criminal behavior control.This paper therefore argues that once the image of theNigeria CJS is rebuilt, through positive behavioral change,for its actors to be accepted as legitimate and credible instruments in ensuring compliance with the law, it then becomes easy to control criminal behaviors among Nigerians as Nigeria CJS actors are significant models for social influence and behavioral change.
\end{abstract}

Keywords: Criminal Justice System, Credibility, Criminal Behavior Control, Nigeria.

\section{INTRODUCTION}

Criminal Justice System (CJS) is an essential part of any civilized nation to ensure justice, fairness, the practice of the rule of law and the institutionalization of a democratic system. The CJS is a system comprising of many bodies, groups, institutions or agencies that have been charged with the responsibilities of ensuring social agreement and mass compliance with the law, and deciding whether or not an individual is guilty of violating the laws of the society, and the appropriate punishment to be meted to such an individual. In addition to such responsibility, the CJS is also responsible for the care and rehabilitation of individuals found guilty of breaking the laws and to whom prescribed punishment is meted out.Anecdotal evidences and a cursory look around one however suggests that something is wrong somewhere particularly considering the waves of crime in Nigeria. Instances of kidnaps for a ransom, incessant killings and armed robbery attacks are daily in the news. More worrisome is the alarming cases of recidivism which then calls to question the usefulness of the rehabilitation and reformatory homes. The question then is, what characteristics of the CJS factors in the effectiveness or otherwise of this system?This paper, thus, focuses on the roles of the Nigeria criminal justice system and its effectiveness in criminal behavior control. The roles and effectiveness of its principal actors are examined and analyzed within relevant theoretical frameworks. For the purpose of this paper, crime is depicted as any act which is against the law and which attracts punishment and/or fine as stipulated by the law. Hence, any reference to crime in this paper captures crimes such as corruption, fraud, bribery, embezzlement, rape, murder, robbery, assault, and so on that violates the laws of the nation.

\section{CRIMINAL JUSTICE SYSTEM: THE CASE OF NIGERIA}

The CJS of a nation represents a system or structure through which the laws guiding the existence and order of such a society is applied and the rights of the citizens are upheld. Certain characteristics have been associated with CJS. They include fairness, justice, equality effectiveness and efficiency (Alemika, 2014; Alemika\&Chukwuma, 2005;Gabbay, 2005). These characteristics spell out equity, offence-punishment proportionality, constitutionality, public order and safety and integrity among other things. Criminal justice implies ascertaining whether or not an accused is guilty of a crime and ensuring that due process is involved in the determination of guilt or innocence and the administration of punishment or compensations as appropriate. Thus, the CJS is a social influencing agent that is concerned with orderliness, peace and tranquility in most societies.In influencing others, behaviors can be regulated and managed. However, if the process of influencing others is, in any form, tainted, then such influence may become either negative, difficult to achieve and, or, may 
be met with outright rebellion and disregard. Therefore in persuading, exerting influence and ensuring compliance, the agents of influence must be credible (Ajzen, 1992; Passer, Smith, Atkinson, Mitchell \& Muir, 2003). A criminal justice system is a system made up of different agents charged with the responsibilities of investigating and prosecuting criminal cases and the correction and rehabilitation of those found guilty of opposing the laws. Evaluation of the effectiveness of the Nigeria CJS is an issue that apparently requires attention; given the seemingly unchecked lawlessness that pervades the nation, the phenomenon and increased rate of recidivism in Nigeria, as in most other societies, and the general opinion and perception of justice as a mirage. Nigeria criminal justice system ought to connote an orderly system within which rights of the citizens are protected and those who err on the side of the law are prosecuted. Thus, it would be an aberration for this same system to be characterized by ineptitude and injustice. Because glaringly, a system whose principal constituents demonstrate utter disregard for the office and purpose for which they are sworn to uphold is an aberration. But Anaedozie (2016), submitted that the management of social order in Nigeria polity poses serious challenges. Okogbule (n.d), argued that from the point of arrest, to investigation, arraignment in court, case hearing, verdict and execution of court verdict, the Nigeria CJS is tainted. Thus, Nigeria seems to continue to struggle with upholding its laws amid myriad criminality that seem beyond the power of the CJS to solve. The principal actors in the Nigeria CJS charged with the responsibility of maintaining one aspect of the law or the other including: the Economic and Financial Crime Commission (EFCC), the Federal Road Safety Commission (FRSC), the Police, the judges, the prisons and so on are often said to be enmeshed in ineptitude, corruption, and injustice. However, this paper focuses on the roles of the police, judges and the prisons. The reason for this choice is that these three actors are the length and breadth of the Nigeria CJS (Martins Library, n.d; Onimajesin, n.d; "The role of prison", 2015). The point from being a suspect to being convicted or acquitted of charges and the execution of sentence of those judged guilty are within the domain of these actors. Furthermore, they are representatives of the government; the bridge between the government and the people. The endemic corruption in the nation has been attributed to the failure of the government to curb this social ill (Anaedozie, 2016). In other words, it could be said that the failure of the CJS, an organ of the government for the maintenance of justice and rule of law, to instigate process that will eliminate corruption, bring to judgment those found guilty of it and to remain corruption-free itself has borne several statements from concerned parties. According to Oyebode (2001) “...corruption ... become our (Nigeria's) fundamental objective and directive principle of state policy". Anaedozie (2016) on the other hand favors the term "grand corruption" which was identified as the "sore spot" obstructing Nigeria's path towards attaining transparency, accountability, effective rule of law, national development and security. Although within the Nigerian make-up, the judiciary connotes the law court. Hence, when the term judicial corruption is referred to, what come to the mind of everyone are the corrupt acts engaged in by judges. However, this paper strongly supports the position of Banjoko (2015) who maintains that the term judicial corruption embraces corrupt acts by all law enforcement agents who share responsibilities in ensuring the due process and credibility of the CJS. Such agents include the police, prosecutors, lawyers, and all other court officials. The popular sentiment is that these agencies or institution have failed and continues to fail to uphold the law and execute the statutory expectations vested on them (Anaedozie, 2016; Osasona, 2016). The Nigeria CJS have been scorned with such derisive statements like "the conveyor belt of injustice from beginning to end" (Amnesty International, 2008) and "Justice is for sale to the highest bidder" (Nigeria, 2010). This explains why the general belief and perception of justice as an illusion in Nigeria holds sway. Nigeria was ranked as the $136^{\text {th }}$ most corrupt country out of the 174 surveyed by Transparency International in their 2014 report and the $3^{\text {rd }}$ most corrupt country in West-Africa, 144th in 2013, 139th in 2012 and 143rd in 2011 (Ejike, 2014). It seems as if Nigerians are becoming numb to acts of criminality and illegality in the nation, since such acts go uncurtailed or uncautioned in the perpetrators. Nigerians seem to have come to accept their fate and survive in a world of chaos. A cursory look at criminal activities that have gone unchecked and have come to be accepted as normal by Nigerians include: careless packing of drivers on the road, the use of cars that are no longer road-worthy, driving without the necessary documents, violating traffic rules, bribery of road-security officials (police, soldiers, FRSC officials), bribery of officials of the law court, road blockage by miscreants called "Area Boys" or "Agberos" who demand money from commercial vehicles and private car owners, blocking of government roads for party use, just to mention a few. One is left to wonder whether there are no laws to caution such unbridled acts as above.Another area in which CJS has failed is in its inability to generate and maintain reliable crime data owing to political and administrative problems (van der Spuy $\&$ Röntsch, 2008). Such statistics, if available, may be used to identify trends in criminal activities and possible link to specific socio-economic or environmental condition triggers. In addition, there will be identification of repeat offenders and available information for policy formulation and implementation. The Centre for Law Enforcement Education [CLEEN], a non-governmental organization established to investigate public opinions of governmental issues conducted a study in 2012 on national crime and safety using 11,518 male and female adults sampled from the 36 states of the federation. The study revealed that the number of people who were afraid of becoming victims of crime increased to $75 \%$ in the year 2012 from the $72 \%$ of the previous year. 1 in 
every 3 participants had actual experience of one form of crime or another in the period covered by the report. Furthermore, only 2 in 12 respondents reported crime victimization to the police with less than half of those who reported being satisfied with the police handling of the case. Those who were not satisfied cited police ineffectiveness, corruption, inadequate feedback and insensitivity as their major reasons. Also there was an increase in bribery and corruption among government agencies of which police, prison workers and court personnel were included. When asked the area to be given priority by the government, crime control got the highest recommendation (CLEEN, 2012). Similarly, a report of a research collaboration in 2015 by Afrobarometer and Transparency International documented that an interview with 43,143 Africans revealed that in Nigeria, $78 \%$ believe the government to be doing badly at curbing corruption; $75 \%$ believed that corruption had increased over the past year and police and the court of law were indicted as being the most corrupt institutions out of the key public services surveyed. People who have had transactions with police and the court were the most likely to have paid bribe and Nigeria was listed as one of the African countries with the highest rate of corruption with a bribery rate higher than that of the regional average (Pring, 2015). Within the above exposition, some actors of the Nigeria CJS will be examined with a view to analyzing their effectiveness as agents of justice. These actors are picked from among others because they are involved in a connecting chain that bounds the CJS from arrest to adjudication and punishment/rehabilitation of individuals found guilty of breaking the law (e. g. Martins Library, n.d; Onimajesin, n.d; "The role of prison", 2015).

\section{The Nigeria Police}

The Nigeria Police is a paramilitary federal institution whose operation is under the control of the President of the country. The Nigeria Police is, by law, vested with the responsibility of detecting, investigating and solving crime so as to ensure peace and stability in the nation. Within the criminal justice system, the police is referred to as the gatekeeper (Alemika, 2014) since they set in motion a criminal case. Within the category of the Nigeria Police Force are other similar organizations like Nigeria Customs Service, Economic and Financial Crimes Commission [EFCC] and Immigration Services, to mention a few (Alemika, 2014; Osiwaju, n.d). From the responsibilities vested in the police as recorded in the Nigeria constitution, criminal cases are initiated by the police who investigate, summons, makes arrest, detain and sets in motion the case. However, when the police are besieged by behaviors that are antithetical to the purpose for which they were established, then the society is set for anomie. According to Wambua (2015), in a survey by Afrobarometer, a pan-African, non-partisan research network that reviews public opinions on issues of governance, democracy and other developmental issues that span more than 30 African countries, it was found that across 34 countries, about half (53\%) of citizens would seek out the police first for assistance in a crime situation. Also, of the 34 countries, the police rank lowest of the trusted public institutions in Nigeria. The report concluded that the police institution is the most corrupt in all the African nations surveyed and issues related to police performance and effectiveness prevented people from reporting crimes to the police.Human Rights Watch (2005) reported that about 900 police officers were dismissed in the year 2004 from the Nigeria Police Force on the ground of extortion.In another report, $51 \%$ of Nigerians expressed dissatisfaction with the police, a figure higher than the Africa average of $45 \%$. While of all security institutions in the nation, the Nigeria Police has the least trust of the citizens with $59 \%$ indicating that they have no trust in the police (Afrobarometer, 2005). Another study conducted in 2003 by CLEEN foundation reported that the Nigeria police's incompetence to curtail corruption, brutality and unruliness undermines public opinion of them. Equally there are incessant reports of police officers violating their code of conduct and the fundamental human rights of citizens. A look at newspapers and other online media publications exemplifies some of the atrocities perpetrated by some officers of the Nigeria police force. The following are excerpts from the media on police misdemeanors

a. "The Nigerian Police Force on Monday said it has arrested an officer ... Mr. Chiyem demanding money in dollars from a Nigerian-American and his two friends. Mr. Chiyem had apparently detained them for alleged traffic related offences..." (Ibeh, 2014).

b. "A heavily drunk policeman was spotted Thursday morning at a popular bustop in Surulere area of Lagos...the man was so drunk that he could barely walk...this happened around 8.45am..." (NaijaGists.com, 2015).

c. "A police officer of the Mobile Police (Mopol) wing..., was caught on camera brutalizing two women... who dipped one severally in mud water and later pointed his riffle at her and threatened onlookers with a shot in the air" (Nigeria Police Watch, 2014).

d. “...Former Inspector General of Police (IGP), Mr. TafaBalogun was yesterday sentenced ... to a six months imprisonment for concealing vital information to the Economic and Financial Crimes Commission (EFCC) over his alleged business concerns... amounting to over N17.7 billion..." (Oji \&Okenwa, 2005).

It is apparent that the resultant effect of a lawless, bribable and corrupt police force is lawlessness and social disarray given the lack of compliance with rules by those who have "bought" the police. A worst case scenario 
is when the police collaborate with criminals to plan and execute crimes. A case in mind is that of the notorious armed-robbery gang comprising of Anini, Monday Osunbor and a police officer named Festus Iyamu in the early 1990s. Iyamu was later revealed as the police officer (DPO) in Benin City who supplies the armed robbery gang with ammunitions for their operations and leaks police information secrets about the gang's arrest to them. Society is unsafe as crime prevails, fundamental human rights violated, and physical and psychological health compromised. This constitutes a contradiction of the purpose of this institution and a violation of their social role. Rather than abate or eliminate crime and maintain peace and order, it exacerbates social vices. As rightly captured by Kumssa (2015), police dishonesty weakens their perceived value and effectiveness in the eye of the citizens.

\section{The Court}

While the police initiate the process of a criminal proceeding, the courts are there to ensure that all due processes are explored in the dispensation of justice. The court's role is to establish, without doubt, the guilt or innocence of individuals brought before her and to ensure that adequate and appropriate punishment or rewards/compensation are given as applicable. In other words, an effective judicial system ensures justice is upheld in all legal proceedings. The courts in Nigeria represent the judiciary and according to the Nigerian constitution, it is saddled with the responsibilities of ensuring fair dispensation of justice. The courts in the country, in order of hierarchy, are: the magistrate/district courts, the high court/sharia/customary court of appeal, court of appeal and the Supreme Court (Olamide, 2016). These courts have the functions of interpreting the law, adjudication and judicial review; and at a more general level, it resolves disputes and enforces the law. However, when the system saddled with the responsibility of dispensation of justice is, itself sometimes, an embodiment of corruption and injustice, then the masses are in trouble. This is because the social order is threatened where it is possible to contradict the law and go scot free. Unfortunately, such is the case in Nigeria. The judiciary have been described as equally corrupt as those arraigned before the court (Akinlotan, 2016). Literature on the performance of the Nigerian judiciary is replete with accounts of corruption, misdemeanor, deliberate misinterpretation of the law, unnecessary delay in legal proceedings, haphazard legal proceedings and violation of rights of the citizens (Edosa\&Fenemigho, 2014; Egbewole\& Imam, 2015; Transparency International, n.d; United Nations Office on Drugs and Crime [UNODC], 2003).

Newspaper accounts of corrupt judges include the following:

a. “...After a thorough investigation...Justice OkwuchukwuOpene... took a bribe of N15,000,000.00... and Justice David AdedoyinAdeniji took a bribe of N12,000,000.00...and three unascertained Ghana-must-Go bags... dismissed those two Justices from the Judicial Bench of Nigeria... " (Otorofani, 2010).

The above account refers tothe Anambra South Senatorial District election petitions' tribunal to settle the election dispute between Nicholas Ukachukwu against that of Dr. UgochukwuUba. The two justice of the court of appeal named above were alleged to have taken bribe to reverse the election result.

$b$. "The figure is startling - 64 of the 1,020 superior court judges have been sanctioned in the past five years for corruption..." (Onanuga, 2015).

The above account of judicial corruption is with no doubt alarming given that these people are supposed to ensure justice and fairness and be the "hope of the common man". What is the hope of a nation whose judiciary is enmeshed in corruption and making a mockery of the constitution of the nation? This, no doubt, affects its credibility in dispensation of justice and protection of the rights of the citizenry. Any instance as above will, no doubt, impact the sanity of a nation and influence learned behaviors.

\section{The Prisons}

Prisons are places where those who have violated the laws of the state are legally held or confined while awaiting trial or serving punishment after being adjudged guilty.Prisons are meant to serve rehabilitation and reformatory purposes where convicted individuals can be made to realize their erroneous ways and the gravity of the acts that led to their conviction, have a change of heart, and, perhaps, acquire certain skills that will enable their re-absorption into the society on completion of their jail sentence (Ndukwe\&Nwuzo, 2014; Nigeria Prisons, n.d; Omagbemi\&Odunewu, 2008). This, at least, was the functions of prison at its inception. However, this is not the case in Nigeria prisons; which are ripe cites for all manners of atrocities. The media is trite with negative reports of what ensues in Nigeria prisons. Prison officials are said to engage in all manners of illegal activities ranging from extortion from inmates and their families, renting of VIP cells, hoarding of gift items from external bodies, stealing of inmates' properties, denial of medical needs, deliberate exposure to 
weather elements, rape, extrajudicial killings, mismanagement of funds, and illegal release of prisoners (Adams, 2015; Hembe, 2016; Onyegbula, 2016). In addition, some states of the federation have been indicted to also operate non-official prisons and detention centers in which extrajudicial killings and inhumane treatments take place (Hembe, 2016). In terms of physical structure, the inmates live under sub-human conditions that are lifethreatening. These include dilapidated structures, poor sanitation and lack of medical facilities. The government has also failed to take any significant step towards reforming the laws that regulate Nigeria prisons which was established in 1947 (Adams, 2015). Furthermore, the Nigeria prisons are congested. It houses 56,785 inmates when it only has a capacity for 49,505 and only $32 \%$ of this population have been tried and convicted according to the Nigeria Prison Services website (Adams, 2015). Also, there is absence of avenue for training and reorientation of the criminal minds of incarcerated individuals for re-absorption into the society on completion of their jail terms, thereby making them unfit to cope with life after prison (Okoroafor, 2015).

With all these existing conditions in Nigeria prisons, it becomes difficult for it to serve the purpose for which it was put in place; that is, to reform prisoners and as a vehicle for the dispensation of justice. Perhaps, the appalling state of Nigeria prisons instigated the statement made by Professor Ben Angwe, the Executive Secretary of the National Human Rights Commission [NHRC] who said "the state of the Nigeria prisons today is a reflection of the state of criminal justice administration in the country" (Okoroafor, 2015).

There are also newspaper accounts of the illegality and aberration to justice that pervades the Nigeria prison system:

Onyegbula (2016) recounts the story of a prison inmate thus:

a. “...Each cell has a marshal who is like the president in charge of the cell. Each marshal buys the position from the warders and generates revenue for the warders...",

b. "...inside the prison, they have special section for VIPS, where inmates who have the resources pay between N30,000 to N100,000 depending on how well furnished the rooms are...” (Onyegbula, 2016).

According to Okoroafor (2015) too, out of the 240 prisons that exist in Nigeria, about 200 of them were built before 1960 and prisoners have to deal with accommodation and facilities that that are archaic and no longer fit for humans.

Attesting to the issue of mismanagement of prison funds also, Uwujaren (2015) wrote that Akon Esu- Nte, the Head of Capital Accounts Unit of the Nigeria Prison Service has been accused of stealing the sum of N200 million.From the above accounts, one is tempted to conclude that Nigeria prisons which was instituted for corrective measures for criminals is also a fertile ground for all manners of criminal activities. Hence, the term correctional facility is more of an oxymoron and an irony when examined in the context of what exists there.

With the increasing rate of crime in Nigeria and worsening of its markers like corruption, there has been numerous studies and clarion calls proposing different approaches to curbing this menace (Anaedozie, 2016; Banjoko, 2015; Edosa\&Fenemigho, 2014; Egbewole\& Imam, 2015; Ekpo, Chime\&Enor, 2016), with each proposing a way out. While some take the point of view of enacting laws, reviewing laws or making punishment more severe, others favor employing more law enforcement agents or retraining existing ones, and imbibing morals or ethics training for the judiciary. However, what is common to all of these approaches is that like all problems that occur on a national scale, people take a policy-approach stance as a way of eradicating the problem thereby failing to consider the people that will make it work.

\section{Psychological Theories/Explanations of Criminal Behavior Control}

Like all psychological investigations of behaviors, be it empirical or theoretical, it begins with describing and understanding the phenomenon. All disciplines study an infinitesimal aspect of different phenomenon. While psychology, as a behavioral science, does not propose a panacea to all social problems, it does contribute meaningfully to understanding how social problems came to be and the individual factors implicated in such. Therefore, questions as regards: why the ineffectiveness of the Nigeria CJS in crime control? And why does the populace no longer see the government and consequently its actors as credible informers; and consequent positive behavioral change agentsare all explainable with a good number of psychological theories and concepts applicable to the understanding of behavior.Such theories include the followings:

1. Theory of planned behavior

2. The concept of the communicator's credibility

3. The concept of foot-in-the-door.

1. Theory of Planned Behaviour (TPB) and The Nigerian Criminal Justice System

In the literature on causal analysis of behavior, the theory of planned behavior has received widespread relevance especially in predicting behavior in a specific context. It connects attitude, beliefs and motivation in explaining human behavior. The theory of planned behavior as proposed by Ajzen (1991) stipulate that an individual's intention to behave in a certain way is influenced by a host of factors. Behavioral intention in a particular context captures the motivating factors that push the individual to want to engage in the said behavior. However, there are independent determining factors in whether such intentions will translate into actual 
behavior. Such factors are: attitude towards the behavior, subjective norms and perceived behavioral control (Ajzen, 1991).

\section{- Attitude}

Whether or not an individual is favorably disposed to performing a particular behavior influences his or her behavioral intention and whether such intentions will manifest in actual behavior. Attitude, which is the positive or negative evaluation of a stimulus, is borne out of considerations of the consequences of such stimulus. In terms of behavior, whether the consequences or outcomes of a behavior are estimated as desirable or undesirable in the individual's opinion comes to determine the attitude that an individual will have towards such a behavior. Hence, with behaviors of anticipated positive consequences, the more favorable attitude towards such will be and vice versa.

\section{- Subjective Norm}

Subjective norm refers to the values and defined normalcy and abnormalcy of behavior by significant others. That is, whether or not significant others have a favorable or unfavorable attitude towards an intended behavior. Subjective norm is underscored by normative belief in the intended behavior. With a perceived favorable attitude of significant others towards an intended behavior, the higher the likelihood to want to engage in such behavior and that intention may be translated into actual behavior and vice versa. Significant others could include family, culture, social norms, law, national orientation and values.

\section{- Perceived Behavioral Control (PBC)}

PBC has to do with whether or not the individual sees the self as having the ability, resources and opportunities with which to realize the performance of an intended behavior (Ajzen, 1991). Ajzen also linked this attribute to the concept of self-efficacy proposed by Bandura, in his social cognitive theory (1986); which refers to appraisal of how well one has the ability to set in motion behaviors that will lead to the execution of a particular action. In addition, perceived behavioral control also captures such factors as the time, opportunity and other resources that may be required to perform the behavior and which the individual considers available or within his or her power to acquire. The more available or acquirable the aids to intended behavior and the less the hurdles to be scaled in performing the behavior, the more individuals perceive the self of being capable to execute the intended behavior.Furthermore, feelings of personal ability to execute behavior may also be informed by the individual's past experiences with the behavior. Experiences of friends, relations, or notable others thus serve as impetus for personal evaluation of ability to execute the behavior. This phenomenon was ably captured in the social learning theory of Bandura (1977) too. The more perceived behavioral control is realistically actual control, the higher its predictive power in behavior. Hence, when an individual has a strong intention to perform a behavior, and such intention is backed by perceived efficacy to make it happen, the behavior is most likely to happen (Ajzen, 1991).Generally, a favorable attitude towards an intended behavior coupled with subjective norms that accept such behavior and a perceived ability to actualize such behavior, the stronger will be the individual's intention to perform the behavior (Ajzen, 1991). However, the weight that each of the components exert in motivating behavior varies with the specific intended behavior and situation (Ajzen, 1991).In a response to the investigation of the sufficiency of the TPB in predicting behavior, Beck and Ajzen (1991), considered the notion of personal feelings of moral obligation in addition to the other components of the model for behaviors with moral implications. In an empirical investigation to test the validity of this fourth component using three unethical behaviors of cheating on a test or exam, shoplifting, and lying to get out of taking a test or turning in an assignment on time; result from hierarchical regression showed that personal feelings of moral obligations contributed more to the explained variance, increasing the models validity in predicting behavior (Beck \&Ajzen, 1991). In applying the TPB to understanding the ineffectiveness of the Nigeria CJS in crime control, the components of the theory can be examined within the Nigeria socio-cultural specifics. How does the Nigeria situation affect her citizen's judgments or evaluation and hence their disposition (attitude) towards crime, their normative belief (subjective norm) about crime and their perception about their ability to execute crime? Do Nigerians have a positive attitude towards crime, do subjective norms favor crime and do people believe in their ability to perpetrate crime?Though there may be no national data on individual Nigerian's favorable or unfavorable disposition towards crime; however, it is no longer news that Nigeria and Nigerians are deeply entrenched in crime to the extent that it is seen as a normal way of life (Afrobarometer, 2005; Anaedozie, 2016; Ashiru, 2016; Gire, 1999). From reports on people's perception of crime, actual involvement in crime, level of corruption of Nigeria and world rating on the nation's involvement in crime, it is apparent that there is systemic crime in Nigeria. It seems that nothing works except with the aid of one criminal act or the other such as bribery, nepotism, stealing, cheating, embezzlement, corruption and so on (Afrobarometer, 2005; Amnesty International, 2008; Anaedozie, 2016; CLEEN, 2012; Pring, 2016; Wambua, 2015; Osasona, 2016). For example, as mentioned earlier, CLEEN (2012) reported that the number of people 
who were afraid of becoming victims of crime increased to $75 \%$ in the year 2012 from the $72 \%$ of the previous year and one in every three participant had actual experience of crime in the period covered by the report. Likewise a research collaboration of Afrobarometer and Transparency International revealed that in Nigeria $75 \%$ believed that corruption had increased over the past year and of the countries surveyed, Nigeria was one of the countries whose citizens had the most negative view of the scale of corruption in the country.

Since actual behavior is a function of attitude, perhaps, it is safe to assume that the increase in corruption and other forms of crime in Nigeria is a product of increasing positive attitude towards crime or acceptance of crime as normal. For example, there seem to be glorification of shady wealth in Nigeria, with emphasis on short-cut to wealth and materialism. What seem to matter is that one has it. How the individual gets it is no man's business (Ashiru, 2016; Gire, 1999; Anatusi\&Nnabuko, 2012). Perhaps there is the increasing conviction that crime pays in the country as those who are rich keep getting richer and the poor are getting poorer, even when the pointers may be there that those riches can, by no means, have been obtained through legal sources. In addition, a lot of crime goes unchecked and people's criminal behavior goes uncensored. There is disobedience of traffic laws by motorists, pedestrians refuse to use bridges made for them, unlawful blockage of road for party purpose because the law enforcement agencies raises no eyebrow (Ashiru, 2016). Nigeria reports on crime shows that between 2005 and 2009, the number of serious crimes reported to the police was 333,368 and between 2009 and 2011 , 837,552 serious crimes were reported to the police (Nigerian Bureau of Statistics [NBS], 2010; 2012).

What is the normative belief about crime in Nigeria? What is the attitude of significant others towards crime? More specifically, what is the attitude of the criminal justice system towards crime? The CJS in Nigeria qualifies as a significant other in that her actors make the rules regarding what and what does not constitute crime and enforce such laws. So what happens when the significant others (CJS) is herself riddled with crime? The activities of the police, the judges and the prisons as discussed earlier glaringly showcase their position on crime. The principal actors of the Nigeria CJS are themselves entrenched in crime. This is boldly evidenced in the bribes and other criminal activities engaged in by police, court judges and prison officials. These actors have been rocked by all manners of scandal that do not depict a reputable CJS. A good example is the current scandal involving corrupt judges who were alleged to have kept corruption money of 1.3 million US Dollars in their homes. One of the judges was reported to have said that a chief judge strategically assign them "lucrative" and high profile cases and then ask them to request bribe in dollars and his share is thus deposited in his home. Accordingly, such cases are then given judgment that favors the highest "bidders" ("Chief Judge of Nigeria's", 2016). It was also reported by some law enforcement officers that some of this corrupt judges had before now been suspected and reported to the National Judicial Council(NJC) headed by the Chief Justice of Nigeria which is the body responsible for monitoring and disciplining judges ("How the Nigerian", 2016). However, the NJC had prevented them from investigating the judges or indicting them even when the body itself found the judges to be guilty. When steps are taken by the NJC, it is mostly to force compulsory retirement on the judges (How the Nigerian, 2016). An Economic and Financial Crimes Commission (EFCC) officer was also reported to have said that some members of the NJC were themselves corrupt and have pending cases of corruption with EFCC ("How the Nigerian", 2016). The Chief Justice of Nigeria was also accused of shielding a judge of the court of appeal who was indicted of an 8 Million Naira bribery charge and recommending her for elevation to the Supreme Court ("How the Nigerian", 2016). Another act that showcases the attitude of the CJS towards crime is the way and manner it investigates and prosecutes those found guilty of criminal activities and the message that it signals to people. At various times in Nigeria, incumbent and ex-governors, ex-presidents and other exgovernment officials have been accused and found guilty of corruption and other crimes while in office. The important question then is: what typically happens to them? For instance, the Babangida's administration (19851993) was found guilty of embezzling \$12.4 billion (Ekpo, Chime \&Enor, 2016). Likewise, General Abdulsalami Abubakar's administration was reported to have misused the sum of N650 billion while Aviation Minister Ms. Stella Oduah concluded her tenure in office despite proof of mismanagement of 255 Million Naira (Ekpo, Chime \&Enor, 2016). Furthermore, former Bayelsa state governor, DiepreyeAlamieyeseigha, who was impeached for corruption and who was reported to have jumped bail, dressed as a woman after being arrested in Britain, was pardoned by President Goodluck Jonathan. The pardon was given two days after receiving his prison sentence, having already spent two years in jail while awaiting verdict and the pardon makes it possible for him to serve in a public office in the future ("Nigeria pardons", 2013; Gambrell, 2013; The African Sun Times, 2015). For those that are actually jailed, what kind of treatment do they receive in prison? For instance, the ex Delta State governor, James Ibori, was reported to have been given special treatment in prison (Isenyo, Kaduna \&Isiguzo, 2007). Even today, after completing his jail term, the media is abashed with videos of the celebration of criminality in Ibori by a Nigeria 'Senator'. Similarly, the then outgoing Inspector General of Police Mr. Abubakar in 2014 was reported to have restored and redeployed Mr. Sam Chukwu, a former Divisional Police Officer (DPO) of Ogui Police Station, Enugu; who was implicated in kidnapping and murder case in 2009 for which he failed to show up for the trial as zonal provost at the Zone 9 headquarters of the Nigerian police based in Umuahia. The inspector general was said to be aware of the pending case of Mr. Sam 
Chukwu and his being a fugitive of justice (Olagunju, 2016).With the above examples and the ones earlier discussed under each of the actors of the CJS, what this system seem to be advocating is that it is favorably disposed to criminal acts. Hence, with a criminal-minded judiciary that makes crime a norm in the Nigeria nation, it may not be a good deterrent to Nigerians who have criminal intentions. For perceived behavioral control of Nigerians in executing criminal acts, the question then is what is to stop one from engaging in crime; if there is a high possibility of getting away with it completely or getting away with minimal punishment? Fresh in memory are the cases of Maina who paid 750 Million Naira fine for embezzling Billions of police officers pension funds, and Cecilia Ibru's plea bargaining after sinking Billions of customers' monies in her Oceanic Bank. What happens with a bribable judiciary where police can be bribed to look the other way, or judges can be bribed to give a favorable verdict or where prison officials can be bribed to give special treatment and make prison-stay comfortable? Looking at the factors that may influence an individual's perception of their selfefficacy in perpetrating crimes like: past experience, the experience of friends and notable others, time and opportunity; one can see how these factors are available to aid perception of behavioral control. When an individual commits a crime and get away with it, then experience have taught that he or she can get away with any crime. Likewise, when other people, including members of the judiciary, commit crimes and get away with it; it can strengthen the resolve of an individual to execute crime. When the delay in judicial processes affords the opportunity for evidences to be buried or for time that should be served in prison to be no longer meaningful having already been served while awaiting verdict, it aids perception of control in executing crime. The influence that models have on behavior is also captured in the proposition of the social learning theory by Bandura (1977) which states that the motivation to imitate and replicate a behavior is influenced by perceived self-efficacy to reproduce the said behavior and the consequences of such behavior to the model. One can readily see, from the accounts given above, how aberrations, corruption and inefficiency of the Nigeria CJS can fuel an individual's intention to engage in criminal behavior and the actual production of the behavior.

With regards to the feelings of moral obligations which has been emphasized in intention to perform behaviors of moral implications; without doubt, crime constitutes behavior of moral implication given its consequences on the society. The question to ask then is, how will feelings of moral obligation and moral sensitivity be aroused in a clime in which immorality and lawlessness are the order of the day? Individual morals draw from societal derived norms, values and traditions. So how does a seemingly immoral society inculcate morals in individuals? How does an immoral CJS enforce morality in the populace? It is conceivable how citizens of an immoral society can justify their criminal acts and indeed absolve the self of guilt by using different techniques of moral disengagement like moral justification, euphemistic labelling and misrepresentation of injurious consequences among others owing to the ineffectiveness of the CJS. Bandura (2002) proposed the concept of moral disengagement to explain how people can avoid feelings of guilt or persuade the self that being morally responsible is not of concern in a particular situation. Moral justification, as a technique of moral disengagement, implies convincing the self that one is morally justified in certain actions. For instance, an individual can justify financial misappropriation and mismanagement as due to non-payment of salary by the employer. Euphemistic labelling involves calling a criminal behavior by another name. For example, amassing wealth at public expense can be called "taking a share of the national cake". Furthermore, an individual can disregard the possible consequences of his/her illegal or criminal behavior. For example, an individual that kidnaps another person for the purpose of obtaining a ransom can convince the self that the individual is rich enough to pay the ransom and that the hostage family will only experience discomfort and fear for just a little while until the ransom is paid and the hostage returned alive.In conclusion, the TPB demonstrates its usefulness and relevance in explaining the spate of crime in Nigeria. The actors of the CJS through their ineffectiveness, inefficiency, corruption and injustice encourage and bolster favorable attitude to crime, showcase normalcy of criminal conducts and encourages the perception that crime is within the power of individuals to commit inadvertently by encouraging criminal intentions. A CJS operating the way it does in Nigeria cannot exert any meaningful influence on the populace because it lacks credibility. The credibility of the communicator has been consistently implied as important in any of forms of persuasion(e. g. Passer et al, 2013, Ajzen, 1992) and in ensuring compliance behavior.

\section{Communicator's Credibility, Cognitive Response Theory and The Nigerian Criminal Justice System}

Communicator's credibility is a concept or strategy for social influence in persuasion. In the literature on communication, advertisement and persuasion, evidence supports the notion of using credible sources in influencing an audience (Ajzen.1992; Harmon \& Coney, 1982; Sternthal, Dholakia \& Leavitt, 1978). Communicator's credibility captures the perceived trustworthiness and expertise of the communicator by the recipient of a message (Ajzen.1992; Myers, \& Spencer, 2001;Passer, et al., 2003). It captures whether, in the opinion of the perceiver or message recipient, the communicator can be trusted and is knowledgeable and confident about the information being passed out. Research into the effectiveness of the source of persuasion have repeatedly shown that trustworthy and expert communicators elicit favorable attitude towards the position 
of the communicator compared to those communicators found to be of less credibility (Harmon \& Coney, 1982; Sternthal et al., 1978). The effect of source credibility has been explained within the framework of Cognitive Response Theory of Greenwald (1968). The theory propose that in a situation of persuasive intentions, the notion of a source's credibility come into play by influencing the activation of thought that negates or supports the position of the communicator in the recipient of the message. The success of persuasion here depends on how favorable the thought activated in the recipient is towards the message received. The thoughts activated in the memory of the recipient are information of relevance in the consideration of the believability of the communicator. This theory predicts that in situations where the message recipient opposes the position of the communicator, a highly credible source will prevent or reduce counter-arguments and will be more likely to succeed in influencing the recipient while a less credible source stimulates the activation of thoughts that promotes counter-argument against the communicator's message (Ajzen, 1992; Greenwald, 1968; McGinnies, 1973; Sternthal et al., 1978). The most effective communicator is one who presents as both trustworthy and an expert on the message (Hovland, Janis \& Kelley, 1953). Factors such as the education, intelligence, attractiveness and social standing of the communicators can give the impression of expertise in the message (Ajzen, 1992).In applying this concept in explaining the lack of effectiveness of the Nigeria CJS, the question then is: Are the different actors of the CJS trustworthy and experts in the responsibility bestowed on them?; Do their behaviors demonstrate that they can be trusted and are knowledgeable about their jobs?; Does behaving in ways which contradict their statutory obligation and ridicule their office not generate doubts in their audience and demonstrate their incapability in doing their job? What credibility does corrupt police officers, judges and prison officials have in ensuring that the masses comply with the law and desist from crime? Can they enforce the laws? Can they exert a positive influence on the populace? Can they ensure compliance with the law?A typical example that demonstrates the mistrust and lack of expertise of Nigeria police is when they stop vehicles and ask for fire extinguisher or extra tyre. An average Nigerian road user is not oblivious of the fact that checking for extra tyre or fire extinguisher is only within the work schedule of the road safety officers. Also, asking for bribe seemingly showcases police officers' lack of awareness of what they stand for as officers of the law and their understanding of their duties as mandated by the constitution. When judges who are meant to interpret and apply the law are themselves guilty of breaking the law, how can they demonstrate their trustworthiness and expertise? The distrust and lack of expertise of prison officials are also demonstrated when a correctional centre is turned into a haven of social vices. This has been largely responsible for the phenomenon of recidivism in Nigeria. How best can a situation in which the police or a police officer drives against traffic be explained for example? Or what does one say of a judge or prison warden who slaps a fellow customer at a filling station because the other person will not allow jumping of queue. With the use of advanced technological gadgets and equipment like Closed Circuit Television (CCTV), satellite, drones, finger print identification system, polygraph test (lie detector), bugs and so on, crime can be apprehended before they happen. It is not uncommon, however, to come across police officers who cannot even communicate coherently or speak more than a smattering of English language, some have little or no education, have no specific training regarding their jobs, do not understand the law or choose to misinterpret it and the police force has no reliable crime database (Alemika\&Chukwuma, 2005; Ugwuegbu, 2011). It is not also uncommon to come across court officials and prison officials who cannot communicate properly. The prison officials in Nigeria lack professional training in rehabilitation or correctional modes of relating with, and managing prisoners (Ugwuegbu, 2011). A lot of Nigerians have travelled abroad to advanced countries and seen how the CJS of such countries work in terms of the training of the staff and how technologically compliant they are. Others have been exposed to simulations of the effectiveness of such CJS in movies and the news. With such exposure to how advanced the CJS of other countries are and compared to what is obtainable here in Nigeria, people might have a little opinion about the preparedness, qualification and expertise of the actors of the Nigeria CJS to fight crime ( drss, 2015; GentleToks, 2015; Ojeifo, 2015; Ugwuegbu, 2011) not even mentioning that it is a compromised institution in the opinion of Nigerians. A last dimension of the non-expertise of the CJS is when cases are dragged on endlessly or unnecessarily delayed until it is out rightly forgotten or dismissed due to the sluggishness of the police and the judgesAs a result of the willingness of these actors of the CJS to look the other way when crimes are committed and to demand payment for rendering their services, Nigerians have become complacent and gotten accustomed to paying their ways through criminal activities ("Nigeria", 2010). A good example is that at check points, passengers of commercial vehicles, especially those undertaking long distance journeys encourage the driver to pay the police officers at the check point to avoid delay. Hence, a driver who does not have the required papers gets away scot free. Judges take bribe and then give favorablejudgments and prison officers exploit prisoners and their family members. A CJS can only exert positive influence on the populace when it is credible. When it is guilty of the same crime it accuses others of committing; it becomes the case of "take the $\log$ out of your own eye first before you can see the speck in my eye of others". It is a common saying in Nigeria that "everyone is corrupt" (Moses, 2016; Ugwu, 2016). If this is the sentiment echoed by all and sundry, it then portends that everyone, including the officers of the law, are seen as corrupt. Then what hope is there in a 
corrupt CJS? Through direct and indirect contact with the CJS and its actors overtime, people form their opinions and perception of this system and its actors. Such opinions and perception are centered on the fairness, legitimacy and credibility of the system. An interaction shapes future interactions and a mode of interpersonal relations is established. People are more willing to comply with the law when they accept the legitimacy of the officers of the law to enforce such laws (Tom \& Jeffrey, 2008). David (2007) affirms that the maintenance of social order and the regulation of personal behavior are predicated on the people's belief that the authorities and their political and legal framework are legitimate. Thus, from the perspective of the communicator's credibility in social influence, the effectiveness and recognition of the legitimacy of the CJS is hinged on building the people's belief in the trustworthiness and expertise of its actors. The concept of the communicator's credibility, no doubt, provides a framework within which the performance of the Nigeria CJS can be analyzed and understood.

\section{Foot-in-the-door (FITD) ("Ask for an inch, then take a mile") and the Nigeria Criminal Justice System}

Another concept in the social influence literature that can be used to explain the ineffectiveness of the Nigeria CJS in criminal behavior control is the technique of foot-in-the-door; a strategy in getting people to comply with one's request. This concept has relevance in the examination of the effectiveness of the Nigeria CJS. The foot-in-the-door is a persuasion technique which involves getting an individual to comply with a small request before making a bigger request (Freedman \& Fraser, 1966). It is a sequential request that starts with a small request in order to gain compliance with a bigger one. Once an individual has been persuaded to comply with the first request, the larger or subsequent demands are more likely to be granted (Freedman \& Fraser, 1966). In explaining why such compliance is achieved, Freedman and Fraser (1966) gave the suggestion that once an individual complies with an initial request, such individual's attitude may change, and consequently become favorable towards such a request; such that the individual come to define the self as one who engages in such a behavior or grants such a request. In applying the FITD concept to the ineffectiveness of the Nigeria CJS, one can examine the following analogies:Over the years, the Nigeria CJS has been presented with various crimes which they allowed to go unpunished. Those who engaged in criminal behavior gradually moved from "little crime" to more heinous ones without the Nigeria CJS taking significant step to curb the behavior. Past and current officials of the government (presidents, governors, ministers and so on) have been indicted of involvement in one form of crime or the other and oftentimes they are able to go scot free. Nigerians have, thus, systematically graduated from minor crimes to major crimes until crimes are perpetrated in broad day light and Nigeria is characterized and tagged as a nation with endemic corruption. It is arguable that the actors of the CJS became persuaded and developed a favorable attitude towards crime since crime already had its foot in the door. It seems to be that actors in the Nigeria CJS were compelled to accede to more criminal behaviors, having allowed criminal acts of lesser magnitude to go unpunished. The mechanism of FITD may also be likened to that of the concept of systematic desensitization in behavior therapy and used in explaining the behavior of the Nigeria CJS. Systematic desensitization is a behavioral therapy in psychology used in reducing or eliminating an individual's fear or anxiety reaction to a stimulus. It involves gradual exposure to the stimulus with increasing gradation of fear-inducing ability, while also attempting to be relaxed. The idea behind this therapy is that one cannot be relaxed and anxious at the same time; hence, the individual is taught to relax while experiencing the fear-inducing stimulus. For a simulation of this effect, one can examine this analogy. The Nigeria CJS is established as a body to maintain justice and fairness and prevent crime. Hence, it is reasonable to assume that any activity bordering on injustice, unfairness and crime should be fear or anxiety-provoking for actors of the CJS since it negates their statutory responsibilities. However, since they seem to be unaware of these responsibilities, perhaps, it can be said that the Nigeria CJS has been systematically desensitized to crime and have had to do away with restraints (anxiety or fear) that may serve as encumbrance since such fear or anxiety cannot augur well in a clime where crime is systemic. Some of the possible relaxation techniques may be through moral disengagement; particularly, one that displaces responsibilities to others and absolve the self of guilt or deliberately misinterpreting the law, delay in legal proceedings and partnering with others to engage in crime. Now, echoing the words of a Nigerian with regards to how corruption (which is one of the criminal acts of utmost concern to Nigeria) started with the military era in Nigeria "the abnormal had become the norm, the illegal had become legal, the outrageous had become banal and aberrant had become the gold standard" (Bakare as cited in Okoye, 2016).Furthermore, while it is the view that all Nigerians are corrupt (Moses, 2016; Ugwu, 2016), when corruption is mentioned in Nigeria, it is most often in emphasis of the corruption in government; particularly of political office holders (Nwodo, 2015). It is believed that corruption in governance spill down to the masses. It is also believed that it is the poor that gets punished for crime while the rich go scot free. Just as discussed previously, that credibility of the communicator is important in wielding influence, such consideration is equally important in effecting a FITD technique in persuasion. The psychology literature on conformity and obedience to authority tells us that people conform and obey authorities when such authorities have a formidable influence, prestige, and exercise some much power. Specifically, it emphasizes the role of institutional authority 
in compliance and conformity behaviors (Kelman\&Hovland, 1953; Milgram, 1963; Myers \& Spencer, 2001; Ornstein, 1991). Authority derived from institutionalized social roles hold particular strength in bringing about obedience (Milgram, 1963; Ornstein, 1991).The question then is who are the communicators of prestige in Nigeria who have used the FITD techniques to persuade and desensitize the Nigeria CJS to crime? Who are those with the authority to ensure the CJS complies with criminality? The public sentiment is that political office holders use their office to perpetrate all manners of corrupt acts and that they work hand in hand with the actors of the CJS, particularly the police and judges, because most of their cases rarely get past these actors and when it proceeds to actual sentencing and serving those sentences; there are usually ways of ensuring a comfortable prison-stay. It is believed that the judges who decide on the guilt or otherwise of public office holders have been bought and work hand in hand with whomever is being indicted to ensure that judgment is in his or her favor. In response to a public demonstration at the National Assembly to institute the death penalty for government officials found guilty of corruption, some Nigerians voiced their opinion online and said that: "Who will kill who? Is it the corrupt judges that will sentence the corrupt politicians? Dogs don't eat dog,", "It can only affect the poor not the rich people, and we know our country and the rich people can buy the mind of the judge with money..." (Nwodo, 2015). A similar opinion has been voiced by other Nigerians (Chidiogo, 2014; Princewill, 2015). For example, (Chidiogo, 2014) stated that "Nigeria is a country where the elites make laws which are only applicable to the poor while the "big shots" only use these laws as a tool through which they show their supremacy". Similarly, a Deputy Senate president Ike Ekweremadu once said "Only the less privileged go to prison in Nigeria" (Chidiogo, 2014) "...those that inhabit the prison are the weak in the society, they are the poor, the unfortunate and those that don't have people to speak for them", “...the rich men are not in prison, not that they don't commit offence but because the web is too weak for the strong and so they can always get out of trouble..."("Only the poor", 2014). So in the opinions of these Nigerians, it is not only political office holders that get away with crime but also the well-to-do in the society. The law can only be binding when no one is above the law. It is understandable why the rich can wield such influence more so when they hold political positions which give them the authority to appoint judges, police and prison officials. It then becomes the case of "reciprocation" or "not biting the hands that fed you" and throwing justice down the drain. For example, the controversial state pardon given to Alamieyeseigha and other ex-convicts in 2013 by President Goodluck Jonathan exemplifies the point that the powerful wields influence in the execution of justice in the Nigeria CJS. All those granted the presidential pardon were at one time or the other in government and were found guilty of crimes including corruption and treason (Daniel, 2013). The pardon was granted by the National Council of State consisting of the President, Vice President, ex-Presidents, all state governors, Chief Justice of the Federation and Senate President among others (DisNaija, 2013). Everyone would readily agree that this group constitute the powerful in Nigeria. Alamieyeseigha was also reported to have said that the President had no choice but to grant him the pardon ("State pardon: Alamieyeseigha", 2013) while the President was also quoted to have said "That is an action that has been taken by the National Council of States and I have no apology for that.", "We must begin to respect and honor our institutions. I don't need to defend the action that has been taken.", "A man was deposed. He was hounded, tried and jailed. What is wrong with giving pardon to a remorseful sinner?" (Ateboh, 2013). One can see how the powerful can affect the course of justice in the nation. There were others convicted of "lesser crimes" that were not reviewed or picked for state pardon. What justification or criteria was used in picking the ex-statesmen for pardon becomes a question. With such occurrence in the nation, one is bound to accept the popular sentiment among Nigerians that justice is as decided by the rich and powerful and that it is a mirage. The FITD exposes that being complacent with a crime can lead to complacent with greater crime. With a pattern of criminality established, a norm may be established and mechanisms put in place to ensure that such norm is perpetuated.

\section{CONCLUSION AND RECOMMENDATIONS}

From the foregoing, it is clear that a credible CJS is the first step towards a sane society. Nigerians cannot continue to see glaringly the abuse of political office, blatant disregard of the rule of law, corruption and other acts of criminality in the institutions or system saddled with the responsibility to provide justice, fairness and social stability and be motivated to be law-abiding. Those in power are models for Nigerians and reference for judging the rightness or wrongness of their behaviors. When such models depict criminality as attractive, then there is a threat to the development of that nation. A central theme in the theories reviewed and applied implies that social justice and fair play is achievable only through a credible CJS. The government should therefore work towards achieving this by instituting a system of incorruptible judges. Perhaps the first point of call is reorientation of these various actors. They should be reminded of what their job is and how it should be done. The value system of these various institutions should be refocused. Rather than a craving for quick wealth, there should be striving for fulfilling statutory responsibilities. These institutions should also be availed the necessary resources to improve their efficiency. Adequate training should be given and at regular intervals, retraining should be done. Offenders should not go unpunished as this sends a wrong signal that "crime pays and 
that one only have to know how to wriggle out of it". Nigerians should also sit up. Corruption and other criminal acts are not limited to those in governance; it is there on the streets. Individuals should curb their desires for unearned and undeserved wealth; favor due process, respect the law and desist from short-cuts to acquire required services from the government. Curbing one's desires for selfish gains, no doubt, is an altruistic act and a moral imperative for the social order of every society. Deciding not to satisfy personal needs and desires at the expense of others is at the heart of peaceful coexistence, particularly in a multi-religious, multi-lingual and multi-tribal nation like Nigeria. Hence, teachings of contentment and hard work should be imbibed in the training of children and modeled by significant others like the teachers, parents, religious leaders and the media. Without doubt; poverty, unemployment, and economic recession is a driving force for criminal acts; an improved economy will go a long way in curbing crime in the nation. Finally, cognitive restructuring for value appreciation and behavioral control is most imperative and recommended; in addition to effective funding and training of prison wardens to enhance rehabilitation and skill acquisition training for offenders to curb recidivism. Also, interrogators should be trained and retrained in the art to reduce false confessions and the distortion of justice.

\section{REFERENCES}

[1] Adams, A. A. (2015, February 13). Legal aid group demands voting rights for prisoners. International Centre for Investigative Reporting. Retrieved from http://icirnigeria.org/legal-aid-group-demands-votingrights-for-prisoners/.

[2] Afrobarometer (2005).Summary of Results: Round 3 Afrobarometer Survey in Nigeria. Available atwww.afrobarometer.org/kenya.htm.

[3] Ajzen, I. (1991). The theory of planned behavior. Organizational Behavior and Human Decision Processes, 50, 179-211.

[4] Ajzen, I. (1992). Persuasive communication theory in social psychology: A historical perspective. In M. J. Manfredo (ed), Influencing human behavior: Theory and applications in recreation, tourism, and natural resource management (pp. 1-27). Champaign, IL: Sagamore Publishing. Retrieved from https://www.researchgate.net/publication/255661892_Persuasive_Communication_Theory_in_Social_Ps ychology_A_Historical_Perspective

[5] Akinlotan, I. (2016, August 7). Angry judges endure tough governmental challenges. The Nation.Retrievedfrom http://thenationonlineng.net/angry-judges-endure-tough-governmental-challenges/.

[6] Alemika, E. E. O. \&Chukwuma, I. C. (Eds.). (2005). Crime and policing in Nigeria: Challenges and options. CLEEN Foundation.1-196.

[7] Alemika, E. E. O. (2014).Crime and public safety in Nigeria.CLEEN Foundation.Pp1-205.

[8] Amnesty International (2008).Nigeria: Criminal justice system is a conveyor belt of injustice says Amnesty. Press Release.Retrieved from https://www.amnesty.org.uk/press-releases/nigeria-criminaljustice-system-conveyor-belt-injustice-says-amnesty.

[9] Anaedozie, F. (2016). Is grand corruption the cancer of Nigeria? A critical discussion in the light of an exchange of presidential letters.European Scientific Journal, 12(5), 11-34.

[10] Anatusi, T. C. \&Nnabuko, J.O. (2012). Corruption and tourism: Restructuring Nigeria's image for development using public relations strategies. Kuwait Chapter of Arabian Journal of Business and Management Review 2(4), 1-17. Retrieved from http://www.arabianjbmr.com/pdfs/KD_VOL_2_4/2.pdf.

[11] Ashiru, T. (2016, Feburary 19). Nigerians are not criminals, but why is there so much crime? Retrieved from http://guardian.ng/business-services/security-watch/nigerians-are-not-criminals-but-why-is-thereso-much-crime/.

[12] Ateboh, M. (2013, March 13). Jonathan confirms pardon for Alamieyeseigha, says, I owe no one apology. Retrieved from http://www.premiumtimesng.com/news/124429-breaking-jonathan-confirmspardon-for-alamieyeseigha-says-i-owe-no-one-apology.html.

[13] Babalola, P. (2015, December 1). Nigeria, police, courts among most corrupt countries, institutions in Africa-TI.TheEagleOnline.Retrievedfrom

https://www.google.com.ng/url?sa=t\&rct=j\&q=\&esrc=s\&source=web\&cd=3\&cad=rja\&uact=8\&ved=0ah ukewjjnooukadpahujisakhei5dukqfggsmai\&url=http\%3a\%2f\%2ftheeagleonline.com.ng\%2fnigeriapolice-courts-among-most-corrupt-countries-institutions-in-africati\%2f\&usg=afqjenfho2lntcw7ywprgcyuqe8sso8joa.

[14] Bandura (1977, 1986)

[15] Bandura, A. (1989). Social cognitive theory.In R. Vasta (Ed.), Annals of child development.Vol. 6.Six theories of child development (pp. 1-60). Greenwich, CT: JAI Press.

[16] Bandura, A. (2002). Selective moral disengagement in the exercise of moral agency.Journal of Moral Education, 31(2), 101 -119.DOI: 10.1080/0305724022014322. 
[17] Beck, I. \&Ajzen, I. (1991).Predicting dishonest actions using the theory of planned behaviour.Journal of Research in Personality, 25, 285-301.

[18] Centre for Law Enforcement Education (2003). Analysis of police and policing in Nigeria: A desk study on the role of policing as a barrier to change or driver of change in Nigeria, (Report prepared for DFID). Lagos: CLEEN.

[19] Centre for Law Enforcement Education (2012). Summary of findings of 2012 national crime and safety survey.CLEEN.Retrieved from http://cleenfoundation.blogspot.com.ng/2012/07/summary-of-findings-of2012-national.html.

[20] Chidiogo, E. (2014, July 25). Who said the rich and influential do not go to prison in Nigeria?.Retrieved from http://ynaija.com/who-said-the-rich-influential-do-not-go-to-prison-see-here/.

[21] Chief Judge of Nigeria's Federal high court implicated in $\$ 1.3$ million bribery arrest.(2016, October 11). SaharaReporters.Retrievedfromhttp://saharareporters.com/2016/10/11/chief-judge-nigeria\%E2\%80\%99sfederal-high-court-implicated-13-million-bribery-arrest.

[22] Cialdini, R. B. \&Trost, M. R. (1998). Chapter twenty-one: Social influence: Social norms, conformity and compliance. Interpersonal Phenomena, 151-192.

[23] Daniel, (2013, March 13). Jonathan grants pardon to former boss, DSP Alamieyeseigha, seven others. Information ng.Retrieved from http://www.informationng.com/2013/03/jonathan-grants-pardon-toformer-boss-dsp-alamieyeseigha-seven-others.html.Information Nigeria.

[24] David, J. S. (2007). Chapter 3: The foundations of legitimacy. In T. R. Tyler (ed), Legitimacy and criminal justice: An international perspective (pp. 30-58). Russell: Sage Foundation. Retrieved from http://www.jstor.org/stable/10.7758/9781610445412.

[25] Deutsch, M. \& Gerard, H. B. (1955).A study of normative and informational social influences upon individual judgment.Journal of Abnormal Social Psychology, 51, 629-36.

[26] DisNaija (2013). President Goodluck Jonathan grants a state pardon to former Bayelsa state governor DiepreiyeAlamieyeseigha and other ex-convicts. Retrieved from http://disnaija.com/naija/presidentgoodluck-jonathan-grants-a-state-pardon-to-former-bayelsa-state-governor-diepreiye-alamieyeseighaand-other-ex-convicts/.

[27] Drss (2015, August 3). Differences between American police and Nigerian police [Web log post].Retrieved from http://www.nairaland.com/2499789/differences-between-american-policenigerian\#36573376.

[28] Edosa, E. \&Fenemigho, E. O. (2014).The Judiciary as an organ of government. An International Multidisciplinary Journal, Ethiopia, 8(3), 92-101. DOI: http://dx.doi.org/10.4314/afrrev.v8i3.7.

[29] Egbewole, W. \& Imam, I. (2015). Nigerian judiciary and the challenge of corruption: Islamic options as panacea. Journal of Islam in Nigeria, 1(1), 84-103. Retrieved fromhttp://www.iwf.com.ng/journal/vol_1_no_1/nigerian_judiciary_challenge_corruption_islamic_optio ns_panacea.pdf.

[30] Ejike, E. (2014, December 4). Nigeria ranks 136th most corrupt country in latest global corruption index. Leadership Newspaper.Retrieved fromhttp://leadership.ng/news/392876/nigeria-ranks-136th-corruptcountry-latest-global-corruption-index.

[31] Ekpo, C. E., Chime, J. \&Enor, F. N. (2016). The irony of Nigeria's fight against corruption: An appraisal of President Muhammadu Buhari's first eight months in office. International Journal of History and Philosophical Research, 4(1), 61-73.

[32] Former Governor DiepreyeAlamieyeseigha, who escaped from London dressed as a woman, dead. (2015, October 10). The African Sun Times. Retrieved from http://africansuntimes.com/2015/10/formergovernor-diepreye-alamieyeseigha-who-escaped from-london-dressed-as-a-woman-dead/.

[33] Freedman, J. L., \& Fraser, S. C. (1966). Compliance without pressure: The foot-in-the-door technique. Journal of Personality and Social Psychology, 4, 195-202.

[34] Gabba, Z. D. (2005). Justifying restorative justice: A theoretical justification for the use of restorative justice practices.Journal of Dispute Resolution, 2, 349-397.

[35] Gambrell, J. (2013, March 13). Nigeria pardons ex-governor who stole millions. Yahoo News.Retrieved from https://www.yahoo.com/news/nigeria-pardons-ex-governor-stole-millions-085453960.html?ref=gs.

[36] GentleToks (2015, February 26).Re: Difference between Nigerian policemen and Canadian policemen. Retrieved from http://www.nairaland.com/2149058/difference-between-nigerian-policemen-canadian/3.

[37] Gire, J. T. (1999). A psychological analysis of corruption in Nigeria.Journal of Sustainable Development in Africa, 1(2).Retrieved from http://www.rrojasdatabank.info/corrupt.htm.

[38] Greenwald, A. (1968). Cognitive learning, cognitive response to persuasion, and attitude change. In Greenwald, A. Brock, T. \&Ostrom, T. (eds.) Psychological foundations of attitudes (pp. 147-170). New York: Academic Press. 
[39] Harmon, R. R. \&Coney, K. A. (1982). The persuasive effects of source credibility in buy and lease situations. Journal of Marketing Research, XIX, 255-6.

[40] Hembe, J. (2016, April 15).Nigerian prison officials steal money meant for prisoners' food - US. Today.ng. Retrieved fromhttps://www.today.ng/news/nigeria/106773/nigerian-prison-officials-stealmoney-meant-for-prisoners-food.

[41] History of the Judiciary: Brief on the Nigeria Judiciary (n.d). Federal Judicial Service Commission.Retrieved fromhttp://fjsc.gov.ng/history-of-the-judiciary/.

[42] Hovland, C. I., Janis, I. \& Kelley, H. H. (1953).Communication and persuasion. New Haven, CT: Yale University Press.

[43] How the Nigerian National Judicial Council shields corrupt judges. (2016, October 11). Sahara Reporters.Retrieved from http://saharareporters.com/2016/10/11/how-nigerian-national-judicial-councilshields-corrupt-judges.

[44] Human Rights Watch (2005). Nigeria: Rest in Pieces. Chapter 5.Human Rights Watch.Retrieved from http://www.hrw.org/reports/2005/nigeria0705/4.htm.

[45] Ibeh, N. (2014, February 3). Nigerian Police arrests officer caught on camera demanding bribe. Premium Times.Retrieved from http://www.premiumtimesng.com/news/154518-nigerian-police-arrests-officercaught-camera-demanding-bribe.html.

[46] Isenyo, G., Kaduna \&Isiguzo, J. (2007, December 12). Fayose, Ibori find solace in books. The nation onlineng.Retrieved fromhttp://www.thenationonlineng.net/archive2/tblnews_Detail.php?id=40918.

[47] Kelman, H. C., \&Hovland, C. I. (1953). Reinstatement of the communicator in delayed measurement of opinion change. Journal of Abnormal and Social Psychology, 48, 327-335.

[48] Kumssa, A. (2015). Police corruption: A perspective on its nature and control. Donnish Journal of Political Science and International Relations, 1(1),1-8. Retrieved from http://donnishjournals.org/djpsir/pdf/2015/march/Asfaw-Kumssa.pdf.

[49] Martins Library (n.d).The effects of Nigeria prison.Retrieved from http://martinslibrary.blogspot.com.ng/2014/06/the-effects-of-nigeria-prison.html.

[50] McGinnies, E. (1973). Initial attitude, source credibility and involvement as factors in persuasion.Journal of Experimental Social Psychology, 9, 285-96.

[51] Milgram, S. (1963).Behavioural study of obedience.Journal of Abnormal Social Psychology, 67, 371378.months. Retrieved from http://nm.onlinenigeria.com/templates/?a=6126.

[52] Moses, C. (2016, October 18). Nigeria can't change when everybody is corrupt - Dr Paul Udensi calls for anti-corruption crusade. ONigeria.Retrieved from http://www.onigeria.com/news/129439.html.

[53] Myers, D. G. \& Spencer, S. J. (2001). Social psychology. Canada: McGraw-Hill Ryerson.

[54] NaijaGists.com (2015, March 5). Photos: Drunk Nigerian police officer caught at Surulere Lagos bustop. NaijaGists.com. Retrieved from http://naijagists.com/photos-drunk-nigerian-police-officer-caught-atsurulere-lagos-bus-stop/.

[55] Ndukwe C. \&Nwuzor C. I. (2014). Nigerian prison service (NPS) and the challenges of social welfare administration: A study of Abakaliki prison. Journal of Policy and Development Studies 9(1).Retrieved from http://www.arabianjbmr.com/pdfs/JPDS_VOL_9_1/2.pdf.

[56] Nigeria Bureau of Statistics (2010).Annual abstract of statistics, 2010. Retrieved from http://www.nigerianstat.gov.ng/pdfuploads/ABS\%202010.pdf.

[57] Nigeria Bureau of Statistics (2012).Annual abstract of statistics, 2012. Retrieved from http://www.nigerianstat.gov.ng/pdfuploads/annual_abstract_2012.pdf.

[58] Nigeria pardons Goodluck Jonathan ally, Alamieyeseigha (2013, March 13). BBC News. Retrieved from http://www.bbc.com/news/world-africa-21769047.

[59] Nigeria police say they have arrested another officer in videotaped bribe scheme (2015, May 13). Sahara Reporters.Retrieved from http://saharareporters.com/2015/05/13/nigeria-police-say-they-have-arrestedanother-officer-videotaped-bribe-scheme.

[60] Nigeria police watch (2014, April 18). Nigeria police officer caught on camera brutalizing women. Nigeria Police Watch.Retrieved from http://www.nigeriapolicewatch.com/2014/04/nigeria-police-officercaught-on-camera-brutalizing-women/.

[61] Nigeria: Corruption fueling police abuses (2010, August 17). Government should rein in extortion, embezzlement, and related abuses. Retrieved from https://www.hrw.org/news/2010/08/17/nigeriacorruption-fueling-police-abuses.

[62] Niyi (2016, August 14). Policeman caught with 126kg of cannabis in Borno. Information ng.Retrieved from http://www.informationng.com/2016/08/policeman-caught-with-126kg-of-cannabis-in-borno.html.

[63] Nwodo, A. (2015). Is death penalty the best way to fight corruption?.Naij.com. Retrieved from https://www.naij.com/464920-is-death-penalty-the-best-way-to-fight-corruption-nigerians-speak-up.html. 
[64] Ojeifo, E. (2015, May 26). Arase, Nigeria police and change.The Guardian.Retrieved from http://guardian.ng/opinion/arase-nigeria-police-and-change/.

[65] Oji, G. \&Okenwa, L. (2005, November 23). Corruption: Balogun pleads guilty, jailed 6 months. Retrieved from http://nm.onlinenigeria.com/templates/?a=6126.

[66] Okogbule, N. S. (n.d). The Nigerian factor and the criminal justice system.1-11.

[67] Okonkwo, (2015, March 17). Two Nigerian police caught fighting in Lagos. OnlineNigeria.Retrieved from http://news2.onlinenigeria.com/latest-addition/404856-two-nigeria-police-caught-fighting-inlagos.html.

[68] Okoroafor, C. (2015, December 28). The Nigerian prison system is an example of why "justice for all" remains beyond reach. Retrieved from http://venturesafrica.com/146135/.

[69] Okoye, R. (2016, August 9). Corruption is official in Nigeria -Pastor Bakare. The Sun.http://sunnewsonline.com/corruption-is-official-in-nigeria-pastor-bakare/.

[70] Olagunju, P. S. (2016, September 25). NOPRIN call for a reopening of case with a view to ensuring justice in the case of Mr. Sam Chukwu who, in 2012, while serving as Divisional Police Officer (DPO) in Enugu state was implicated in high level kidnapping and murder and escaped from justice. Police Monitor. Retrieved from http://www.policemonitor.ng/2016/09/noprin-calls-for-a-reopening-of-kidnapand-murder-case/.

[71] Olamide, O. (2016, March 21). Hierarchy of courts.jet Lawyer. Retrieved from http://www.djetlawyer.com/hierachy-of-cpourts/.

[72] Omagbemi, C.O. \&Odunewu, A.O. (2008).An appraisal of library service provision to prison inmates in Nigeria. Lagos: Tolu Express Republic.

[73] Onanuga, A. (2015, June 30). Weeding out corrupt judges.The Nation.Retrieved from http://thenationonlineng.net/weeding-out-corrupt-judges/.

[74] Onimajesin, S. I. (n.d.). Criminal justice system in Nigeria: An appraisal. Pp 195-205.

[75] Only the Poor Go to Prison in Nigeria (2014, July 19). Nigeria News Beat.Retrieved from http://www.nigerianewsbeat.com/only-poor-go-prison-nigeria.

[76] Onyegbula, E. (2016, July 9). Nigerian prison where inmates pay between N30,000 to N100,000 to watch movies, use iPhones and iPads. Vanguard.Retrieved http://www.vanguardngr.com/2016/07/nigerian-prison-inmates-pay-n30000-n100000-watch-movies-useiphones-ipads/.

[77] Ornstein, R. (1991). The evolution of consciousness: Of Darwin, Freud and cranial fire: The origins of the way we think. New York: Prentice-Hall.

[78] Osasona, T. (2016).Time to reform Nigeria's criminal justice system.Journal of Law and Criminal Justice, 3(2), 73-79. DOI: 10.15640/jlcj.v3n2a7.

[79] Osiwaju, K. (n. d.). Police accountability in Nigeria. Lagos: CLEEN Foundation. Pp 3-4.

[80] Otorofani, F. (2010, December 9). Nigerian Judiciary Reinvented as the Ultimate Rigging Machine. FocusNigeria.com. Retrieved from http://www.focusnigeria.com/democracy-in-nigeria-part4.htm.

[81] Oyebode, A. (2001). An overview of corruption in Nigeria: Political reforms and economic recovery in Nigeria. Lagos: Nigerian Institute of Advanced Legal. Retrieved from http://www.econbiz.de/Record/anoverview-of-corruption-in-nigeria-oyebode-akin/10001801662.

[82] Passer, M. W., Smith, R. E., Atkinson, M. L., Mitchell, J. B. \& Muir, D. W. (2003). Psychology frontiers and applications. Canada, McGraw-Hill Ryerson.

[83] Princewill, T. (2015, December 2). Do only the poor go to jail in Nigeria? Vanguard.Retrieved from http://www.vanguardngr.com/2015/12/do-only-the-poor-go-to-jail-in-nigeria/.

[84] Pring, C. (2015). People and corruption: Africa survey 2015-Global corruption barometer. A joint publication by Transparency International and Afrobarometer.1-48.Retrieved from http://www.informationng.com/2013/03/jonathan-grants-pardon-to-former-boss-dsp-alamieyeseighaseven-others.html.Information Nigeria.

[85] Skogan, W. \&Frydl, K. (Eds.). (2004). Fairness and effectiveness in policing: The evidence. Committee to Review Research on Police Policy and Practices; Committee on Law and Justice; Division of Behavioral and Social Sciences and Education; National Research Council. Washington DC: The National Academic Press. DOI: 10.17226/10419.

[86] State pardon: Alamieyeseigha says Jonathan had no choice. (2013, May 21). Sahara Reporters.Retrieved from http://saharareporters.com/2013/05/21/state-pardon-alamieyeseigha-says-jonathan-had-no-choice.

[87] Sternthal, B., Dholakia, R. \& Leavitt, C. (1978). The persuasive effect of source credibility: Tests of cognitive response. Journal of Consumer Research, 4, 252-260.

[88] The role of prison institutions in the criminal justice system. (2015, March 1). The Leader News Online.Retrieved from http://theleaderassumpta.com/2015/03/01/the-role-of-prison-institutions-in-thecriminal-justice-system-1/. 
[89] Three judges sacked for judicial malpractices (2016, July 17). PM NEWS. Retrieved from: http:// www.pmnewsnigeria.com/2016/07/17/3-judges-sacked-for-judicial-malpractices/.

[90] Transparency International (n.d).Judiciary.Transparency International.Retrieved from http://www.transparency.org/topic/detail/judiciary.

[91] Ugwu, R. (2016, August 4). Every Nigerian is corrupt -GovAjimobi. The Sun news online.Retrieved from http://sunnewsonline.com/every-nigerian-is-corrupt-gov-ajimobi/.

[92] Ugwuegbu, D. C. E. (2011). Social psychology and social change in Nigeria: A systematic evaluation of government social policies and programmes. Retrieved from https://books.google.com.ng/books?id=Nocfs166LRgC\&pg=PA355\&lpg=PA355\&dq=nigerians+compar e+the+nigerian+police+to+those+outside+the+country\&source=bl\&ots=6CNv7HQRFs\&sig=DgogOdyS eXY_Y_BS2EvZVJ6b8V4\&hl=en\&sa=X\&ved=0ahUKEwjZoILbsubPAhUBXRQKHRVMA14Q6AEIR

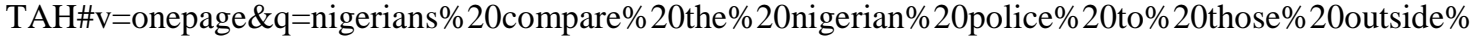
20the $\% 20$ country $\& \mathrm{f}=$ false.

[93] United Nations Office on Drugs and Crime (2003).Strengthening judicial integrity and capacity in Nigeria. Progress Report \# 2.pp 1-61.

[94] Uwujaren, W. (2015, April 16). How Nigeria's prison accountant, Akon Esu-Nte squandered prisons funds- Witness. naija247news .Retrieved from http://naija247news.com/2015/04/how-nigerias-prisonaccountant-akon-esu-nte-squandered-prisons-funds-witness/.

[95] Van der Spuy, E. \&Röntsch, R. (2008).Police and crime prevention in Africa: A brief appraisal of structures, policies and practices. Draft reported on October 31st Cape Town.

[96] Wambua, P. M. (2015).Police corruption in Africa undermines trust, but support for law enforcement remains strong. Afrobarometer Dispatch No. 56. 